\title{
RUNO LEŚNE W POLSKIM PORZĄDKU PRAWNYM - UWAGI DE LEGE LATA I DE LEGE FERENDA
}

\section{UNDERGROWTH IN THE POLISH LEGAL SYSTEM - DE LEGE LATA AND DE LEGE FERENDA REMARKS}

\section{STRESZCZENIE}

Runo leśne jest jednym ze składników ekosystemów leśnych. Stanowi ono także istotne pojęcie ustawy o lasach. Przedmiotem opracowania jest analiza regulacji prawnych dotyczących runa leśnego, jego ochrony oraz pozyskiwania płodów. Rozważania obejmują problematykę runa leśnego w kontekście: (1) zasad gospodarki leśnej (zasady ciągłości i zrównoważonego wykorzystania wszystkich funkcji lasów, zasady trwałości utrzymania lasów) oraz (2) zasad udostępniania lasów (przemysłowe i niehandlowe pozyskiwanie płodów runa

Doktor nauk prawnych, adiunkt w Katedrze Prawa Administracyjnego i Prawa Administracyjnego Gospodarczego Kolegium Prawa Akadaemii Leona Koźmińskiego, Biuro Orzecznictwa Naczelnego Sądu Administracyjnego. 
leśnego). Podstawowym celem artykułu jest przegląd wybranych regulacji prawnych (ustawy o lasach, Kodeksu wykroczeń) pod kątem zapewnienia ochrony oraz trwałości użytkowania (płodów) runa leśnego. Na tym tle sformułowano wnioski de lege ferenda, które - zdaniem autora tekstu - przyczynią się do większej efektywności ochrony runa leśnego oraz trwale zrównoważonego i racjonalnego pozyskiwania jego płodów.

\section{Słowa kluczowe}

Runo leśne; płody runa leśnego; produkty ubocznego użytkowania lasu; udostępnianie lasu; użytkowanie lasu; zasady gospodarki leśnej; gospodarka leśna; trwale zrównoważona gospodarka leśna.

\section{ABSTRACT}

Undergrowth is one of the components of forest ecosystems. It is also an important notion of the Act on Forests. The object of this study is the analysis of legal regulations concerning undergrowth, its protection and extracting its products. The deliberations include the issue of undergrowth in the context of: (1) principles of forest management (the principle of continuity and sustainable use of all forest functions, the principle of the persistent maintenance of forests) as well as (2) the principles under which forests are to be made accessible (extracting the products of undergrowth for industrial purposes and own needs of people). The fundamental aim of this article is to review selected regulations (of the Act on Forests, the Code of Petty Offences) paying special attention to ensure the protection and sustainability of use of undergrowth and its products. In this context, de lege ferenda conclusions were reached, which - according to the author of the text - are supposed to contribute to more efficient protection of undergrowth and sustainable as well as rational extraction of its products.

\section{Keywords}

Undergrowth; products of the forest floor vegetation; by-products of forest usage; access to forests; forest usage; forest management principles; forest management; sustainable forest management. 


\section{WPROWADZENIE}

Najbardziej charakterystycznym elementem lasu są drzewa, a ściślej rzecz ujmując ich większe skupiska określane - na gruncie nauk przyrodniczych - mianem drzewostanów ${ }^{1}$. Bez względu na rodzaj drzewostanów oraz ich pochodzenie (np. nasadzenia sztuczne lub naturalny samosiew) stanowią one podstawowy, ale nie jedyny składnik ekosystemów leśnych. Należy bowiem pamiętać, że las jest złożonym układem rozmaitych elementów (roślinności, świata zwierzęcego, klimatu lokalnego, stosunków wodnych, gleby) powiązanych wzajemnymi wpływami oraz współzależnościami² ${ }^{2}$.

Jednym ze składników lasu jest runo leśne - pojęcie występujące w przepisach ustawy z dnia 28 września 1991 r. o lasach $^{3}$. Celem niniejszego artykułu jest przeprowadzenie analizy uregulowań problematyki runa leśnego oraz - tam, gdzie to możliwe i pożądane - sformułowanie postulatów de lege ferenda. Znajduje to swoje uzasadnienie $\mathrm{w}$ tym, że runo leśne będąc $-\mathrm{w}$ rozumieniu ustawy o lasach - istotnym komponentem gospodarki leśnej z jednej strony, a także wymagającym racjonalnego gospodarowania produktem ubocznego użytkowania lasu z drugiej strony, nie doczekało się, jako pojęcie prawne, bliższej i nade wszystko - jurydycznej refleksji. Niniejsze opracowanie jest, w zamyśle jego autora, podjęciem próby przynajmniej częściowego wypełnienia tej luki.

1 W botanice podkreśla się wprost, że las jest formacją roślinną, w której zasadniczą rolę odgrywają drzewa. Zob. Słownik botaniczny, Warszawa 2003, s. 449. Natomiast definicję legalną drzewostanów zawiera ustawa z dnia 7 czerwca 2001 r. o leśnym materiale rozmnożeniowym (Dz.U. z 2001 r. Nr 73 poz. 761). Zgodnie z art. 2 pkt 2 ppkt 2 tego aktu prawnego, drzewostan oznacza „zespół drzew o zbliżonych cechach morfologicznych, rosnących w bezpośrednim sąsiedztwie i wzajemnie na siebie oddziałujących".

2 Mała encyklopedia leśna, S. Kocięcki (red.), Warszawa 1991, s. 257-258 .

3 Tekst jedn. Dz. U. z 2014 r., poz. 1153, dalej cyt.: u.l. lub ustawa o lasach. 


\section{RUNO LEŚNE - UWAGI OGÓLNE I OKREŚLENIE POJĘCIA}

Gospodarka leśna stanowi fundamentalną gałąź gospodarki narodowej $\mathrm{i}$ - zgodnie z art. 6 ust. 1 pkt 1 u.l. - oznacza „działalność leśną w zakresie urządzania, ochrony i zagospodarowania lasu, utrzymania i powiększania zasobów i upraw leśnych, gospodarowania zwierzyną, pozyskiwania - z wyjątkiem skupu - drewna, żywicy, choinek, karpiny, kory, igliwia, zwierzyny oraz płodów runa leśnego, a także sprzedaż tych produktów oraz realizację pozaprodukcyjnych funkcji lasu".

Powyższa definicja legalna wskazuje na, ujęte przez ustawodawcę i możliwe do wyodrębnienia, kluczowe funkcje lasów, do których zalicza się funkcje produkcyjne oraz pozaprodukcyjne (ekologiczne i społeczne). Pierwsze z nich „kojarzą się przede wszystkim z wytwarzaniem (siłami przyrody i pracą człowieka) drewna, użytków ubocznych (zwierzyny, grzybów, owoców runa leśnego, żywicy, ziół, kory, choinek, stroiszu) oraz z pozyskiwaniem zwierzyny"4. Natomiast drugie z wymienionych funkcji dotyczą korzystnego wpływu ekosystemów leśnych na środowisko oraz życie człowieka ${ }^{5}$.

Funkcja produkcyjna lasów związana jest więc ściśle $\mathrm{z}$ ich użytkowaniem polegającym na wykorzystywaniu „naturalnych bogactw leśnych aktualnie i potencjalnie możliwych do wykorzystania przez człowieka"6. W naukach leśnych wyróżnia się dwa podstawowe rodzaje użytkowania lasów: główne oraz uboczne. Przedmiotem głównego użytkowania lasu jest pozyskiwanie surowca drzewnego (drewna) ${ }^{7}$, podczas gdy „cele i zadania ubocznego użytkowania lasu dotyczą maksymalnego gospodarczego wykorzystywania leśnych produktów i surowców ubocznych bez szkody dla środowiska leśnego"s.

4 R. Jaszczak, Funkcje lasów, [w:] Propedeutyka leśnictwa, W. Kusiak, R. Jaszczak, Poznań 2009, s. 63.

5 Tamże, s. 62-63.

6 P. Paschalis, Założenia do zasad u̇̇ytkowania lasu $w$ koncepcji trwałego i zrównoważonego gospodarowania lasami, „Sylwan” 1997, Nr 1, s. 49.

7 Podstawy gospodarki leśnej, B. Ważyński (red.), Poznań 2014, s. 287.

8 Tamże, s. 348. 
Uboczne użytkowanie lasu wykształciło się, w ujęciu historycznym, wcześniej niż użytkowanie główne - towarzyszyło i służyło człowiekowi od najdawniejszych lat ${ }^{9}$. Obecnie jest ono klasyfikowane w oparciu o kryterium pochodzenia użytków ubocznych, co pozwala wyodrębnić ich trzy zasadnicze rodzaje: (1) użytki pochodzenia roślinnego (np. żywica, kora, grzyby, owoce leśne, itp.); (2) użytki pochodzenia zwierzęcego (np. zwierzyna, skóry, produkty pszczelarskie) oraz (3) użytki wydobywane z ziemi (kopaliny) ${ }^{10}$.

Jednym z rodzajów użytków ubocznych są płody runa leśnego, mieszczące się $\mathrm{w}$ pierwszej $\mathrm{z}$ wymienionych grup. Ustawa o lasach nie definiuje pojęcia (płodów) runa leśnego, dlatego konieczne jest - w celu ustalenia jego znaczenia - sięgnięcie do dorobku nauk przyrodniczych, w tym także nauk leśnych. Z punktu widzenia botaniki, runo leśne to „stosunkowo małe i krótko żyjące, niezdrewniałe rośliny, mianowicie bezkwiatowe, rozmnażające się przez jednokomórkowe zarodniki - grzyby, porosty, mszaki i paprotniki, oraz kwitnące i rozmnażające się przez nasiona trawy i zioła"11. W leśnictwie jest ono postrzegane w nieco odmienny sposób, centralnym punktem odniesienia jest w tym przypadku ekosystem leśny. Stąd też mianem runa leśnego określa się tutaj najniższą warstwę roślinności w drzewostanie, składającą się z roślin zielnych, mchów, porostów oraz grzybów ${ }^{12}$.

Dotychczasowe rozważania wskazują, że pojęcie płodów runa leśnego jest pojęciem o węższym zakresie znaczeniowym niż produkty (surowce) ubocznego użytkowania lasu - runo leśne jest rodzajem surowców niedrzewnych, jakimi są użytki pochodzenia roślinnego z dolnych (najniższych) warstw roślinności drzewostanów. Ta uwaga jest o tyle istotna, że ustawodawca posługuje się - w przepisach ustawy o lasach - zarówno

9 P. Staniszewski, W. Ł. Nowacka, Leśne pożytki niedrzewne jako dziedzina nauki oraz element gospodarki leśnej, „Studia i Materiały Centrum Edukacji Przyrodniczo-Leśnej” 2014, r. 16, z. 38, s. 62.

10 W. Grochowski, Uboczna produkcja leśna, Warszawa 1990, s. 14.

11 G. Amann, Rośliny runa, Warszawa 1994, s. 7.

12 Mała encyklopedia..., s. 459. 
pojęciem runa leśnego jak i pojęciem produktów i surowców ubocznego użytkowania lasu.

\section{RUNO LEŚNE W GOSPODARCE LEŚNEJ}

Określone w powyższy sposób runo leśne stanowi jeden z konstytutywnych elementów normatywnej koncepcji ekosystemów leśnych, uregulowanej w art. 3 u.l. Przepis ten statuuje dwie definicje lasów, które łączy fakt, że lasem jest zawsze grunt: 1) przeznaczony do produkcji leśnej; 2) stanowiący rezerwat przyrody lub wchodzący w skład parku narodowego; 3) wpisany do rejestru zabytków albo 4) związany z gospodarką leśną (zajęty pod budynki wykorzystywane do jej prowadzenia, szkółki leśne, drogi leśne, etc.). Są to więc kryteria uznawania gruntów za las ${ }^{13}$, przy czym w przypadku trzech pierwszych z nich, aby określony grunt mógł zostać uznany za las, muszą zostać spełnione łącznie jeszcze dwa warunki: po pierwsze, powierzchnia gruntu nie może być mniejsza niż 0,10 ha i po drugie, grunt musi porastać roślinność leśna (uprawy leśne), do której ustawodawca zalicza drzewa, krzewy oraz runo leśne. Widać wyraźnie, na co zwraca uwagę W. Radecki, że normatywna koncepcja lasów zdecydowanie różni się od definicji formułowanych w naukach przyrodniczych ${ }^{14}$. Nie zmienia to jednak faktu, że jej integralnym składnikiem - także w definicji legalnej zawartej w ustawie o lasach - pozostaje runo leśne.

Pozyskiwanie płodów runa leśnego, o czym wspomniano już wcześniej, jest jednym z rodzajów działalności leśnej prowadzonej w ramach gospodarki leśnej. Gospodarka leśna stosownie do art. 8 u.l. - opiera się na czterech explicite wyod-

13 Zob. np. Wyrok NSA z 11 kwietnia 2014 r., II OSK 2735/12, www.orzeczenia.nsa.gov.pl i przywołana w orzeczeniu literatura, Wyrok WSA w Warszawie z 26 maja 2015 r., IV SA/Wa 930/15, www.orzeczenia.nsa.gov.pl.

14 W. Radecki, Ustawa o lasach. Komentarz, Warszawa 2012, s. 35. 
rębnionych zasadach: powszechnej ochrony lasów, trwałości utrzymania lasów, ciągłości i zrównoważonego wykorzystania wszystkich funkcji lasów, a także powiększenia zasobów leśnych. Można sformułować tezę, że wszystkie spośród wymienionych zasad w sposób pośredni odnoszą się do runa leśnego, ze względu na fakt, że jest ono składnikiem lasów. Jednocześnie połowa spośród wyliczonych zasad, w zasadzie wprost obejmuje swoim zakresem problematykę najniższych warstw lasu. Bezpośrednio kwestię runa leśnego, jak również pozyskiwania jego płodów normują te przepisy ustawy o lasach, które dotyczą i uszczegóławiają zasadę ciągłości i zrównoważonego wykorzystania wszystkich funkcji lasów oraz zasadę trwałości utrzymania lasów.

\subsection{RUNO LEŚNE A ZASADA CIĄGŁOŚCI I ZRÓWNOWAŻONEGO WYKORZYSTANIA WSZYSTKICH FUNKCJI LASÓW}

Stosownie do art. 7 u.1., istota zasady ciągłości i zrównoważonego wykorzystania wszystkich funkcji lasów polega na realizacji trwale zrównoważonej gospodarki leśnej prowadzonej według planu urządzenia lasu lub uproszczonego planu urządzenia lasu z uwzględnieniem szeregu wskazanych przez ustawodawcę celów. Trwale zrównoważona gospodarka leśna została zdefiniowana jako „działalność zmierzająca do ukształtowania struktury lasów i ich wykorzystania w sposób i tempie zapewniającym trwałe zachowanie ich bogactwa biologicznego, wysokiej produkcyjności oraz potencjału regeneracyjnego, żywotności i zdolności do wypełniania, teraz i w przyszłości, wszystkich ważnych ochronnych, gospodarczych i socjalnych funkcji na poziomie lokalnym, narodowym i globalnym, bez szkody dla innych ekosystemów" (art. 6 ust. 1 pkt 1a u.1.). Jest ona jednym z modeli gospodarki leśnej ściśle związanej z obowiązującą koncepcją wielofunkcyjnej gospodarki leśnej, ukierunkowanej „na zachowanie równowagi wymogów ekologicznych oraz interesów ekonomicznych i potrzeb socjal- 
nych społeczeństwa"15. Wielofunkcyjny model gospodarki leśnej jest pochodną idei zrównoważonego rozwoju i opiera się na eksponowaniu także pozaprodukcyjnych funkcji lasów, tj. funkcji ochronnych, ekologicznych oraz socjalnych ${ }^{16}$. Nie oznacza to rzecz jasna, że gospodarcze funkcje lasów są marginalizowane. Chodzi tutaj raczej o harmonizowanie poszczególnych funkcji lasów ${ }^{17}$ oraz pozwalające na odnawianie tych funkcji, korzystanie (użytkowanie) z - jak stanowi ustawodawca - udostępnianych lasów. Powyższe uwagi znajdują pełne odzwierciedlenie w definicji legalnej omawianego modelu gospodarki leśnej, która kładzie szczególny nacisk na ekonomiczne, ekologiczne oraz socjalne (społeczne) funkcje lasów, a ściślej na podjęcie działań umożliwiających zapewnienie ich zrównoważonego współwystępowania.

Realizacja zasady ciągłości i zrównoważonego wykorzystania wszystkich funkcji lasów wymaga wykonywania określonych w ustawie o lasach działań, w szczególności zaś czynności z zakresu gospodarki leśnej określonych w art. 6 ust. 1 pkt 1 u.1. ${ }^{18}$. Chodzi tutaj przede wszystkim o urządzanie, ochronę, zagospodarowanie lasu, utrzymanie i powiększanie zasobów i upraw leśnych, ale także realizację pozaprodukcyjnych funkcji lasów. Działania te powinny być prowadzone według podstawowych dokumentów gospodarki leśnej jakimi są plany urządzenia lasów oraz ich uproszczone formy.

Dodatkowo wymienione czynności powinny uwzględniać sygnalizowane wcześniej cele, do których zalicza się przede wszystkim: zachowanie lasów oraz ich korzystnego wpływu na składniki środowiska naturalnego i równowagę przyrodniczą; ochronę lasów ze szczególnym uwzględnieniem ekosystemów

15 L. Płotkowski, Ekonomiczne aspekty oceny funkcji lasu, czyli gospodarka leśna w koncepcji zrównoważonego rozwoju, „Studia i Materiały Centrum Edukacji Przyrodniczo-Leśnej" 2008, r. 10, z. 3, s. 253.

16 L. Płotkowski, S. Zając, Opracowanie modelu wielofunkcyjnej gospodarki leśnej w regionie rolniczym, Warszawa 2004, s. 1.

17 J. Chmielewski, Zasady ogólne gospodarki leśnej i prawa leśnego, „Krytyka Prawa. Niezależne studia nad prawem" 2015, T. 7, s. 112.

18 Zob. Wyrok NSA z 9 września 2015 r., II OSK 95/14, www.orzeczenia. nsa.gov.pl. 
leśnych cennych przyrodniczo i stanowiących naturalne fragmenty rodzimej przyrody, ochronę gleb oraz terenów o istotnym znaczeniu społecznym, a także szczególnie narażonych na zanieczyszczenie czy ochronę wód (powierzchniowych, głębinowych, retencji zlewni). Ponadto - co wydaje się szczególnie istotne z punktu widzenia niniejszych rozważań - zgodnie z art. 7 ust. 1 pkt 5 u.l., trwale zrównoważoną gospodarkę leśną prowadzi się z uwzględnieniem celu jakim jest produkcja, na zasadzie racjonalnej gospodarki drewna oraz surowców i produktów ubocznego użytkowania lasu.

Powyższe przepisy dają asumpt do sformułowania wniosku, że prowadzenie trwale zrównoważonej gospodarki leśnej realizującej zasadę ciągłości i zrównoważonego wykorzystania wszystkich funkcji lasów to $\mathrm{w}$ istocie podejmowanie i prowadzenie działań zmierzających do ukształtowania struktury lasów i - jednocześnie - ich wykorzystania w sposób zrównoważony (oparty na koncepcji ekorozwoju). Natomiast celem przyjętego przez ustawodawcę modelu gospodarki leśnej jest m.in. produkcja surowców i produktów ubocznych użytkowania lasu, a więc i runa leśnego. Innymi słowy, jednym z celów gospodarki leśnej jest pozyskiwanie (produkcja) runa leśnego, ale warunkiem koniecznym prowadzenia tego typu działalności leśnej jest jej racjonalny charakter. Przy czym u podstaw „racjonalnej” gospodarki leży optymalizacja korzyści, co oznacza, że - jak zauważa J. Pakuła - jest to gospodarka wykorzystująca nowoczesne (naukowe) metody, pozwalająca osiągać dobre wyniki. Dlatego też, zdaniem Autora, jest ona zorientowana na zysk i w konsekwencji może budzić uzasadnione wątpliwości, czy rzeczywiście przyjmuje charakter zrównoważony ${ }^{19}$.

\subsection{RUNO LEŚNE A ZASADA TRWAŁOŚCI UTRZYMANIA LASÓW}

Nie kwestionując zasadności tego poglądu, nie można tracić z pola widzenia faktu, że zarówno główne jak i uboczne

19 J. Pakuła, Pojęcie i zasady gospodarki leśnej, [w:] Wybrane problemy prawa leśnego, B. Rakoczy (red.),Warszawa 2010, s. 86-87. 
użytkowanie lasów (w tym płodów runa leśnego) jest działaniem - z punktu widzenia trwałości ekosystemów leśnych - nie tylko nieszkodliwym, ale wręcz pożądanym ${ }^{20}$. Jednakże obligatoryjnym warunkiem jest tutaj podejmowanie działań oraz (gospodarcze) korzystanie z lasów w sposób, który nie zagrozi utrzymaniu ich trwałości - w tym sensie korzystanie z lasów powinno przyjąć charakter zrównoważony. Powyższa konstatacja znajduje pełne odzwierciedlenie w nałożonych przez ustawodawcę na właścicieli lasów obowiązkach trwałego utrzymywania lasów i zapewnienia ciągłości ich użytkowania. Obowiązki te statuuje art. 13 u.l. stanowiący normatywne uszczegółowienie wyrażonej w art. 8 pkt 2 u.l. zasady trwałości ich utrzymania. W najbardziej generalnym ujęciu jest to zasada gospodarki leśnej i prawa leśnego regulująca obowiązkowe działania właścicieli lasów polegające na pielęgnowaniu i ochronie lasów czy przebudowach drzewostanów. Ponadto swoim zakresem zasada trwałości utrzymania lasów obejmuje problematykę runa leśnego oraz korzystania z jego surowców (płodów), zaś tak skonstruowany przez ustawodawcę katalog preferowanych zachowań i pożądanych czynności właścicieli lasów wskazuje, że priorytetem jest ochrona lasów ${ }^{21}$.

Zgodnie bowiem z art. 13 ust. 1 pkt 1 u.l. właściciele lasów są obowiązani do zachowania w nich m.in. roślinności leśnej (upraw leśnych) oraz - jak stanowi pkt 2 przepisu - ponownego wprowadzania tej roślinności w okresie 5 lat od usunięcia drzewostanu. Jest to o tyle istotne, że - stosownie do art. 3 zawierającego normatywną definicję lasów - w zakresie zna-

20 Dokładnie tę problematykę wyjaśnia R. Poznański, który dowodzi, że „trwałość lasu i jego efektywną ochronę można zapewnić przez utrzymanie dynamicznej równowagi pomiędzy procesami: odnawiania, przeżywania i ubywania drzew i drzewostanów na płaszczyźnie gospodarstwa leśnego (...). Istota utrzymania trwałości istnienia i ochrony lasu tkwi zatem nie w zakazie użytkowania i w biernej ochronie, ale w regulowanej przez człowieka relacji pomiędzy wzajemnie ze sobą powiązanymi trzema procesami biologicznymi". R. Poznański, Trwałość lasu i regulacja a ochrona przyrody w lasach, „Studia i Materiały Centrum Edukacji Przyrodniczo-Leśnej” 2014, r. 16, z. 39, s. 58.

21 Wyrok NSA z 11 kwietnia 2014 r., II OSK 2735/12, , www.orzeczenia. nsa.gov.pl. 
czeniowym pojęcia roślinności leśnej (upraw leśnych) mieszczą się nie tylko drzewa, ale także krzewy oraz - co szczególnie istotne - runo leśne. Wynika stąd, że bez względu na formę własności lasów ${ }^{22}$, obowiązkiem ich właścicieli jest także podejmowanie działań mających na celu zachowanie runa leśnego. Jak bowiem wskazuje się w naukach leśnych, „definicja trwałości lasu odnosi się wprawdzie do warstwy drzew, ale nie jest zawężeniem tego pojęcia"23 i obejmuje - poza drzewostanami także inne składniki lasów. Nie ulega więc wątpliwości, że zachowanie (utrzymywanie) runa leśnego - elementu roślinności leśnej, jest jednym z warunków trwałego utrzymywania lasów i zapewnienia ciągłości ich użytkowania. Dlatego też to właśnie przede wszystkim ponowne wprowadzanie roślinności leśnej może stanowić treść obowiązku orzeczonego w decyzji administracyjnej wydawanej przez starostę w sytuacji, gdy właściciel lasu niestanowiącego własności Skarbu Państwa nie wykonuje tego zadania (art. 24 pkt 1 u.l.) ${ }^{24}$. W judykaturze sądowo-administracyjnej przyjmuje się, że z art. 24 u.l. wynika ciążący na właścicielu lasu obowiązek przywrócenia stanu poprzedniego lasu poprzez ponowne wprowadzenie roślinności leśnej (upraw leśnych) i doprowadzenia np. do odtworzenia leśnego charakteru gruntu (np. runa leśnego) ${ }^{25}$. Chodzi tutaj o tzw. restytucję runa leśnego ${ }^{26}$, polegającą na przywróceniu tego składnika lasu

22 Zob. definicję właściciela lasu zawartą w art. 6 ust. 1 pkt u.l.

23 R. Poznański, Trwałość lasu..., s. 56.

24 W przypadku lasów stanowiących własność Skarbu Państwa jest to przedmiotem działalności Państwowego Gospodarstwa Leśnego Lasów Państwowych, które tymi lasami zarządzają i prowadzą w nich w sposób stały i zorganizowany gospodarkę leśną w oparciu o określone w ustawie o lasach zasady. Stąd też zaniechanie tego rodzaju obowiązków przez jednostki organizacyjne PGL LP nie odbywa się w postępowaniu jurysdykycjnym (dotyczy bowiem sfery wewnętrznej administracji leśnej), przyjmując formę aktów kierownictwa wewnętrznego, poleceń służbowych czy zarządzeń.

25 Wyrok WSA w Warszawie z 18 maja 2011 r., IV SA/Wa 540/11, www.orzeczenia.nsa.gov.pl, wyrok WSA w Warszawie z 6 marca 2015 r., I SA/Wa 1092/14, www.orzeczenia.nsa.gov.pl.

26 H. Będkowska, Niezbędnik edukatora, Warszawa 2010, s. 99. 
w procesie sukcesji (docierania z innych ekosystemów leśnych) lub regeneracji ${ }^{27}$.

Wspomniane wcześniej kontrowersje dotyczące racjonalnej gospodarki leśnej oraz jej ewentualnych sprzeczności z koncepcją trwale zrównoważonej gospodarki leśnej (zob. pkt 3.1 niniejszego opracowania) w pewnym sensie znosi, a w każdym razie znacząco niweluje dyrektywa postępowania wyrażona W art. 13 ust. 1 pkt 5 u.l. W świetle rzeczonego przepisu lasy powinny być wprawdzie użytkowane racjonalnie (co słusznie może kojarzyć się z maksymalizacją efektywności realizacji funkcji gospodarczych), ale jednocześnie ustawodawca zastrzega, że ich użytkowanie musi w sposób trwały zapewniać optymalną realizację wszystkich jego funkcji, a zatem także funkcji pozagospodarczych. Dokonuje się to przez: po pierwsze, pozyskiwanie drewna w granicach nieprzekraczających możliwości produkcyjnych lasu oraz po drugie, pozyskiwanie surowców i produktów ubocznego użytkowania lasu w sposób zapewniający możliwość ich biologicznego odtwarzania, a ponadto ochronę runa leśnego. Adresatami tego przepisu są wszyscy właściciele lasów, którzy wprawdzie nie zawsze są zobligowani do wykonywania wszystkich zadań z zakresu prowadzenia gospodarki leśnej (np. osoby fizyczne będące właścicielami lasów nie wykonują działalności leśnej w zakresie urządzania lasu, powiększania zasobów i upraw leśnych, gospodarowania zwierzyną), ale ich bezwarunkowym obowiązkiem - bez względu na formę własności - jest trwałe utrzymanie i zapewnienie ciągłości użytkowania swojego lasu' ${ }^{28}$. Obowiązek ten dotyczy także ochrony runa leśnego oraz pozyskiwania jego płodów w sposób zapewniający możliwość ich biologicznego odtwarzania.

27 A. Orczewska, Ł. Depa, Rola rozkładającego się drewna i zasiedlających go mrówek $w$ migracji roślin runa leśnego, „Studia i Materiały Centrum Edukacji Przyrodniczo-Leśnej" 2014, r. 16, z. 41, s. 365-366.

28 Wyrok WSA w Warszawie z 25 września 2013 r., IV SA/Wa 947/13, www.orzeczenia.nsa.gov.pl. 


\section{RUNO LEŚNE W KONTEKŚCIE UDOSTĘPNIANIA LASÓW}

Pozyskiwanie płodów runa leśnego powinno więc odbywać się w sposób racjonalny ale i (trwale) zrównoważony. Jest to fundamentalny warunek prawidłowej realizacji zasady trwałości utrzymania lasów, którą należy respektować bez względu na formę ich własności. W tym miejscu trzeba jednak postawić następujące pytanie: czy ta zasada, a w szczególności wynikająca z niej konieczność zrównoważonego pozyskiwania płodów runa leśnego oraz jego ochrona, jest w ogóle możliwa do zrealizowania w sytuacji, gdy lasy stanowiące własność Skarbu Państwa (a zatem zdecydowana większość ekosystemów leśnych) udostępniane są dla ludności? Oczywistym następstwem powszechnego dostępu do lasów jest, z jednej strony, wykorzystywanie ich $\mathrm{w}$ celach rekreacyjnych $\mathrm{w}$ formie wypoczynku, wędrówek, itp., natomiast z drugiej strony - determinowane historycznie, kulturowo czy ekonomicznie - pozyskiwanie przez ludność płodów runa leśnego. Bez względu na motywacje ludzi oraz charakter korzystania z lasów, jedną z konsekwencji powszechnego do nich dostępu jest antropopresja, której istotnym aspektem pozostaje negatywny wpływ człowieka na runo leśne ${ }^{29}$.

\subsection{REGLAMENTACJA UDOSTĘPNIANIA LASÓW ZE WZGLĘDU NA DEGRADACJĘ RUNA LEŚNEGO}

Problematykę runa leśnego w kontekście udostępniania lasów - w tym zarówno jego ochronę jak i pozyskiwanie płodów - regulują postanowienia ustawy o lasach, statuując w tym zakresie różnego rodzaju unormowania ${ }^{30}$. Po pierwsze, przepisy ustawy o lasach przewidują ograniczenia (wyjątki) od zasa-

29 Zob. np. A. Janusz, M. Piszczek, Udostępnianie lasów dla potrzeb turystyki i rekreacji na obszarze Regionalnej Dyrekcji Lasów Państwowych w Krakowie, „Studia i Materiały Centrum Edukacji Przyrodniczo-Leśnej” 2012, r. 14, z. 32 , s. 52-60.

30 Jednocześnie, jak zauważa L. Bielecki, ustawa o lasach „nie formułuje sposobu udostępniania lasów należących do Skarbu Państwa”, L. Bielecki, 
dy udostępniania lasów polegające na możliwości wprowadzania okresowych zakazów wstępów do lasów, jeżeli wystąpiła degradacja runa leśnego (art. 26 ust. 3 pkt 1 u.l.). W takich przypadkach właściwy miejscowo nadleśniczy wydaje generalny akt administracyjny, który dotyczy potencjalnie każdego i wyłącza gwarantowane ustawowo uprawnienia (dostęp do lasów), co powinno nastąpić dopiero po stwierdzeniu - w ramach postępowania wyjaśniającego - rzeczywistej degradacji runa leśnego na określonym obszarze. W obowiązującym stanie prawnym nadleśniczy wydając okresowy zakaz wstępu do lasu, nie jest jednak związany żadnymi rygorami znajdującymi oparcie w przepisach procesowych ${ }^{31}$. O ile więc podmioty, których zakaz bezpośrednio dotyczy (każdy, kto chce wejść do lasu w celu np. zbioru płodów runa leśnego) nie biorą i nie mogą brać udziału w wydaniu przez nadleśniczego okresowego zakazu wstępu do lasu, o tyle - zdaniem J. Zimmermanna - mogłyby one zaskarżyć tego rodzaju generalny akt administracyjny do wojewódzkiego sądu administracyjnego w oparciu o art. 3 $\S 2$ pkt $4^{32}$ ustawy z dnia 30 sierpnia 2002 r. Prawo o postępowaniu przed sądami administracyjnymi ${ }^{33}$. Należy w pełni zgodzić się, że objęcie kognicją sądów administracyjnych okresowych wstępów do lasów wyposaża obywatela w środki ochrony jego interesu prawnego oraz gwarantuje prawo do sądu ${ }^{34}$. Ponadto zapewnia kontrolę legalności tych generalnych aktów administracyjnych, w szczególności zaś poddaje ocenie sądu, czy ustalenia nadleśniczego w zakresie rzeczywistej degradacji runa leśnego były prawidłowe.

Koncepcja rzeczy publicznej $w$ prawie polskim. Zagadnienia administracyjnoprawne, Kielce 2013, s. 211.

31 E. Szewczyk, M. Szewczyk, Generalny akt administracyjny, Warszawa 2014, s. 142.

32 J. Zimmermann, Aksjomaty prawa administracyjnego, Warszawa 2013, s. 134.

33 Tekst jedn. Dz. U. z 2012 r., poz. 270 ze zm.

34 J. Zimmermann, Aksjomaty..., s. 134; J. Zimmermann, Prawo administracyjne, Warszawa 2014, s. 430-431. 


\subsection{NIEHANDLOWE POZYSKIWANIE RUNA LEŚNEGO}

Po drugie, runo leśne jest - w lasach zarządzanych przez PGL Lasy Państwowe - własnością Skarbu Państwa, ale jednocześnie ustawodawca dopuszcza możliwość jego pozyskiwania, rozróżniając zbiór płodów runa leśnego na potrzeby własne oraz dla celów przemysłowych. Zbiór płodów runa leśnego na potrzeby własne należy rozumieć jako uprawnienie polegające na pobieraniu tych płodów dla celów osobistych, niehandlowych ${ }^{35}$. Nieodpłatny charakter korzystania z pozaprodukcyjnych zasobów naturalnych Skarbu Państwa dla potrzeb własnych ludności - w tym niekomercyjny zbiór płodów runa leśnego - potwierdza art. 5 ust. 1 ustawy z dnia 6 lipca 2001 r. o zachowaniu narodowego charakteru strategicznych zasobów naturalnych $\mathrm{kraju}^{36}$.

Zagadnieniem budzącym duże kontrowersje jest nadmierne pozyskiwanie runa leśnego na potrzeby własne. W przypadku jagód i grzybów (ale dotyczy to także innych płodów runa leśnego) mówi się wprost o „(...) niekontrolowanej i niczym nieograniczonej eksploatacji" ${ }^{37}$. Podstawowym problemem jest tutaj zbiór płodów runa leśnego przez ludność, a następnie ich odsprzedaż podmiotom prowadzącym tego rodzaju działalność gospodarczą ${ }^{38}$. Niewątpliwie znajduje to swoje uzasadnienie w sytuacji ekonomicznej dużej części ludności (głównie na terenach wiejskich), ale - w dłuższej perspektywie - prowadzi do zachwiania równowagi przyrodniczej i trwałości utrzymania lasów. Dlatego też „dalsze tolerowanie obecnych zachowań w la-

35 A. Stelmachowski, Wykonywanie własności nieruchomości, [w:] System prawa prywatnego. Tom 3. Prawo rzeczowe, T. Dybowski (red.), Warszawa 2007, s. 272.

36 Dz. U. z 2001 r., Nr 113, poz. 1068. Zob. interesujące uwagi dotyczące pojęcia „lasów państwowych” wprowadzonego przepisami tej ustawy: A. Haładyj, J. Trzewik, Pojęcie strategicznych zasobów naturalnych - uwagi krytyczne, „Przegląd Prawa Ochrony Środowiska” 2014, Nr 1, s. 36-37.

37 A. Ankudo-Jankowska, J. Glura, Znaczenie produktów ubocznego użytkowania lasu dla gospodarki leśnej, „Forestry Letters” 2013, T. 104, s. 100.

38 D. Pawełek, Zbieractwo grzybów, owoców, ziót i innych dóbr runa leśnego - zagrożenie i nadzieje, „Panacea” 2010, Nr 4, s. 16. 
sach zbieraczy płodów runa leśnego jest niemożliwe. Koniecznością staje się podjęcie działań uniemożliwiających eksploatację, wręcz rabunkowy system pozyskiwania tych użytków z lasu"39. Jak się wydaje, obecne regulacje nie stanowią skutecznych podstaw do ograniczenia rabunkowego pozyskiwania płodów runa leśnego. Są one bowiem niewystarczające. Poza unormowaniami w ustawie o lasach obejmują przede wszystkim przepisy rozporządzenia Ministra Ochrony Środowiska, Zasobów Naturalnych i Leśnictwa z dnia 28 grudnia 1998 r. w sprawie szczegółowych zasad ochrony i zbioru płodów runa leśnego oraz zasad lokalizowania pasiek na obszarach leśnych ${ }^{40}$. Wprawdzie pewną rolę odgrywają w tym zakresie także inne akty wykonawcze (rozporządzenie Ministra Środowiska z dnia 9 października 2014 r. w sprawie ochrony gatunkowej grzybów ${ }^{41}$ oraz Rozporządzenie Ministra Środowiska z dnia 9 października 2014 r. w sprawie ochrony gatunkowej roślin ${ }^{42}$ ), ale - jak wskazuje W. Radecki - w załączonych do nich wykazach roślin i grzybów nie ma typowych roślin i grzybów pozyskiwanych jako płody runa leśnego ${ }^{43}$. Ponadto oba akty podustawowe normują przede wszystkim ochronę grzybów i roślin (wprowadzając określone zakazy, odstępstwa od zakazów oraz sposoby ochrony), natomiast w zdecydowanie mniejszym stopniu (szczątkowo) odnoszą się do problematyki ich pozyskiwania.

Rozporządzenie MOŚZNiL, poza ogólnymi zasadami zbioru płodów runa leśnego korespondującymi z regulacji ustawy o lasach, stanowi o dopuszczalności zbioru owocników grzybów jadalnych bez oznak rozkładu, ręcznym - tj. bez użycia jakich-

39 P. Paschalis, Założenia..., s. 54.

40 Dz. U. 1999, nr 6, poz. 42, dalej cyt.: rozporządzenie MOŚZNiL.

41 Dz.U. z 2014 r. poz. 1408.

42 Dz.U. z 2014 r. poz. 1409.

43 W Radecki, Ustawa..., s. 197. Uwaga Autora dotyczyła wprawdzie wcześniejszych rozporządzeń, ale porównanie ich załączników z rozporządzeniami obowiązującymi zasadniczo raczej potwierdza aktualność tej tezy. Warto jednak zauważyć, że w załącznikach do obowiązujących aktów doprecyzowano i dookreślono np. sposoby pozyskiwania mchów czy grzybów objętych ochroną częściową, które mogą być pozyskiwane. Na temat zmian w ochronie grzybów zob. B. Gmaj, Ochrona gatunkowa grzybów w prawie polskim, „Przegląd Prawa Ochrony Środowiska” 2015, Nr 2, s. 201-202. 
kolwiek narzędzi i urządzeń niszczących lub uszkadzających rośliny - zbiorze ich owoców, a także wprowadza obowiązek używania małych łopatek, noży ogrodniczych lub sekatorów, siatek i płacht przy pozyskiwaniu całych roślin lub ich części (§ 4 rozporządzenia MOŚZNiL). Jednocześnie zbiór grzybów lub owoców leśnych w miejscach zabronionych lub gdy odbywa się to sposobem niedozwolonym, zagrożony jest karą grzywny (do 250 zł) lub naganą (art. 153 § 1 pkt 3 ustawy z dnia 20 maja 1971 r. Kodeks wykroczeńn ${ }^{44}$ ). Pojęcie niedozwolonego sposobu zbioru grzybów lub owoców obejmuje np. „(..) rozgarnianie ściółki w poszukiwaniu grzybów, niszczenie grzybów i grzybni, wreszcie wszelkie sposoby zbierania prowadzące do niszczenia lub uszkadzania roślin, w tym np. zbieranie borówek za pomocą grzebienia oraz inne naruszenia rozporządzenia (MOŚZNiL przyp. mój - J. Ch.) z 28.12.1998 r." ${ }^{\text {" }}$. Warto jednak zwrócić uwagę, że gramatyczna oraz literalna wykładnia art. $153 \S 1$ k.w. nie pozostawia wątpliwości, iż niedozwolony sposób zbiorów odnosi się wyłącznie do grzybów oraz owoców, podczas gdy rozporządzenie MOŚZNiL reguluje także odpowiedni sposób pozyskiwania roślin (całych lub ich części). W pojęciu roślin mieszczą się np. zioła - jeden z elementów runa leśnego. Równocześnie art. $153 \S 1$ pkt 2 k.w. penalizuje zbieranie m. in. właśnie ziół (w nienależącym do zbierającego lesie). Wydaje się, że de lege ferenda przepis ten powinien zostać zmieniony. Zioła mogą być przecież zbierane jako runo leśne (na własne potrzeby), chodzi raczej o to, że nie można ich pozyskiwać bez zastosowania małych łopatek, noży ogrodniczych lub sekatorów, siatek i płacht. Można byłoby rozważyć włączenie ziół do art. 153 $\S 1$ pkt 3 k.w., albo zawarcie - w art. $153 \S 1$ pkt 2 tego aktu prawnego - zastrzeżenia o niedozwolonych sposobach zbioru tych elementów runa leśnego. Istnieje jeszcze jedna możliwość, a mianowicie włączenie pojęć runa leśnego oraz płodów runa leśnego do materii k.w. Jest zastanawiające, dlaczego ustawodawca nie posługuje się tymi kategoriami, skoro stanowią one

44 Tekst jedn. Dz.U. z 2015 r. poz. 1094, dalej cyt.: k.w.

45 W. Radecki, [w:] M. Bojarski, W. Radecki, Kodeks wykroczeń. Komentar\%, Warszawa 2013, s. 924. 
istotne pojęcia w ustawie o lasach. Osobiście uważam, że byłoby to najlepsze rozwiązanie, zwłaszcza że zioła nie wyczerpują składników runa leśnego wyliczonych w art. 153 § 1 k.w. Zostały tam bowiem wyodrębnione także inne rośliny dna ekosystemów leśnych, takie jak: wrzosy czy mech. Stąd też postulowana regulacja (jeden z punktów art. 153 k.w.) mogłaby przyjąć następujące brzmienie: Kto w nienależącym do niego lesie: zbiera runo leśne lub pozyskuje jego płody w miejscach, w których jest to zabronione, albo sposobem niedozwolonym, podlega karze grzywny do 250 zł albo karze nagany.

Ponadto można byłoby rozważyć interwencję prawodawczą polegającą na wprowadzeniu limitów ilości płodów runa leśnego, jakie mogą być pozyskiwane. Przykładowo szereg państw UE określiło, ile kilogramów grzybów może zebrać jeden obywatel ${ }^{46}$. Unormowania tego rodzaju mogłyby znaleźć się w ustawie wraz z normą upoważniającą do wydania aktu wykonawczego. W rozporządzeniu należałoby ustanowić ilości płodów runa leśnego, jakie - dla danego gatunku - mogą być pozyskiwane. Rozporządzenie podlegałoby corocznej aktualizacji dokonywanej w oparciu o inwentaryzację oraz prognozowane wielkości baz surowcowych runa leśnego. Takie inwentaryzacje są prowadzone chociażby przy okazji sporządzania leśnych planów urządzeniowych ${ }^{47}$. Dodatkowo prowadzi się odrębne rozpoznania bazy surowcowej runa leśnego „za pomocą ankiet, bezpośrednich prac terenowych i na podstawie ilości zebranych płodów runa leśnego zapisanych w księgach gospodarczych lub łącznie wszystkimi sposobami"48. Nie istnieją więc żadne przeszkody ujęcia tego rozpoznania w autonomiczne ramy normatywne.

46 A. Ankudo-Jankowska, J. Glura, Znaczenie..., s. 105.

47 Rozporządzenie Ministra Środowiska z dnia 9 października 2014 r. w sprawie ochrony gatunkowej grzybów oraz rozporządzenie Ministra Środowiska z dnia 9 października 2014 r. w sprawie ochrony gatunkowej roślin przewidują wprawdzie inwentaryzację, ale gatunków grzybów i roślin objętych ochroną ścisłą i częściową. Ponadto poza zakresem regulacji tych aktów podustawowych znajdują się inne gatunki runa leśnego.

48 S. Głowacki, Zasoby leśnych surowców ubocznych oraz możliwości ich wykorzystania przez LP, Warszawa 2002, s. 15. 


\subsection{PRZEMYSŁOWE POZYSKIWANIE PŁODÓW RUNA LEŚNEGO}

Po trzecie, problematyka runa leśnego w kontekście udostępniania lasów, dotyczy także - poza zbieraniem runa na własne potrzeby - jego pozyskiwania dla celów przemysłowych. Jak podkreśla się w doktrynie, zbiór płodów runa leśnego na potrzeby własne jednostki to powszechne korzystanie z lasów, podczas gdy czynienie tego samego, ale w innym celu, w tym przemysłowym, jest korzystaniem szczególnym ${ }^{49}$.

Artykuł 27 ust. 2 u.l. dopuszcza zbiór płodów runa leśnego dla celów przemysłowych na podstawie umowy zawartej z nadleśnictwem. Swoboda zawarcia takiej umowy doznaje ograniczeń w przypadku, gdy zbiór runa leśnego zagraża środowisku - w tej sytuacji nadleśniczy, stosownie do art. 27 ust. 3 u.l., może odmówić zawarcia umowy. Powyższe uregulowania są zbyt ogólne, a przez to nieprecyzyjne. Jak wskazuje B. Rakoczy, nie jest jasne, czy umowa o zbiór płodów runa leśnego dla celów przemysłowych jest wzajemna i odpłatna (czy zachodzi tutaj ekwiwalentność świadczeń). Ponadto przedmiotowe regulacje niewłaściwie określają strony umowy (nadleśnictwo, a nie Skarb Państwa) oraz nie precyzują, jaki podmiot jest jej drugą stroną (zbieracz czy też przedsiębiorca prowadzący działalność gospodarczą) $)^{50}$. Dlatego też, jak konstatuje Autor, ustawa o lasach wymaga „zmian w zakresie stosunków obligacyjnych, które ona reguluje. (...) Regulacje te nie są zadowalające zarówno jeśli chodzi o przedmiot regulacji, jak i o określenie stron umowy. Ustawodawca wydaje się podchodzić do zagadnień umów w ustawie o lasach z lekceważeniem prawa cywilnego. Widać brak dbałości o język prawny, charakterystyczny dla prawa cywilnego. Prawodawca używa takich pojęć, które w prawie cywilnym oznaczają zupełnie co innego niż instytucja, którą chciał on uregulować w danym przepisie (np. użytkowanie, przekazanie). Niewłaściwie też określa on strony umowy

49 D. Kijowski, Rzeczy i urzadzenia publiczne, [w:] System prawa administracyjnego, T. 7, Prawo administracyjne materialne, R. Hauser, Z. Niewiadomski, A. Wróbel (red.), s. 437.

50 B. Rakoczy, Ustawa o lasach. Komentarz, Warszawa 2011, s. 143. 
(np. nadleśniczy, a nie Skarb Państwa)"51. Należy w pełni podzielić pogląd o konieczności jednoznacznego uregulowania problematyki umów o pozyskiwanie płodów runa leśnego dla celów przemysłowych. Znajduje to swoje uzasadnienie $\mathrm{w}$ tym, że - jak pokazują badania statystyczne - w Polsce z roku na rok znacząco zwiększają się ilości pozyskiwanych płodów runa leśnego ${ }^{52}$. Stąd pożądanym byłoby bardziej precyzyjne, a w każdym razie prawidłowe uregulowanie tej problematyki, w celu zagwarantowania pewności obrotu prawnego.

Powyższe uwagi prowadzą do wniosku, że obowiązujące regulacje ustawowe oraz podustawowe dotyczące ochrony i przede wszystkim pozyskiwania płodów runa leśnego jako formy udostępniania lasów, mogą być niewystarczające do zapewnienia realizacji zasady trwałości utrzymania ekosystemów leśnych. Wobec tego można byłoby rozważyć proponowane zmiany stanu normatywnego, co mogłoby - przynajmniej w jakiejś mierze - przyczynić się do poprawy tego stanu rzeczy.

\section{RUNO LEŚNE W USTAWIE 0 OCHRONIE PRZYRODY}

Pojęcie runa leśnego nie występuje - jako kategoria normatywna - na gruncie przepisów ustawy z dnia 16 kwietnia 2004 r. o ochronie przyrody ${ }^{53}$. Nie oznacza to jednak, że runo leśne pozostaje poza reżimem ochronnym statuowanym posta-

51 B. Rakoczy, Wprowadzenie do prawa leśnego, [w:] Wybrane problemy prawa leśnego, B. Rakoczy (red.),Warszawa 2011, s. 29. Na temat tych regulacji krytycznie wypowiada się także M. Walas, Korzystanie z lasów a trwale zrównoważona gospodarka leśna, [w:] Prawne aspekty gospodarowania zasobami środowiska. Korzystanie z zasobów środowiska, B. Rakoczy, M. Szalewska, K. Karpus (red.), Toruń 2014, s. 374.

52 A. Piwowar, Zasoby leśne - Baza surowcowa $i$ znaczenie $w$ agrobiznesie, „Journal of Agribusiness and Rural Development” 2015, Nr 1, s. 101-106. Na przykład w latach 2008-2012 wartość dynamiki wzrostu skupu owoców leśnych zwiększyła się ponad trzykrotnie, natomiast grzybów leśnych prawie dwukrotnie, Tamże, s. 105.

53 Tekst jedn. Dz. U. z 2016 r., poz. 442, dalej cyt.: u.o.p. lub ustawa o ochronie przyrody. 
nowieniami tego aktu normatywnego. Przystępując do omówienia koncepcji ochrony runa leśnego $\mathrm{w}$ ramach systemu ochrony przyrody, należy w tym miejscu jeszcze raz przypomnieć, że najogólniej mówiąc - runo leśne obejmuje grzyby i efemeryczne rośliny.

Zasadniczo runo leśne (rośliny i grzyby) - w materii ustawy o ochronie przyrody - jest chronione na dwa sposoby. W pierwszej kolejności można wskazać tutaj ochronę w ramach wyodrębnionych przez ustawodawcę form ochrony przyrody (art. 6 ust. 1 u.o.p.), w szczególności zaś niektórych form obszarowych, takich jak parki narodowe oraz rezerwaty przyrody. Przepisy ustawy o ochronie przyrody jednoznacznie zakazują pozyskiwania, niszczenia lub umyślnego uszkadzania roślin oraz grzybów na terenach parków narodowych i rezerwatów przyrody (art. 15 ust. 1 pkt 5 u.o.p.). Ponadto ustawodawca wprowadza - wśród form ochrony przyrody - ochronę gatunkową roślin i grzybów (a także zwierząt). Stosownie do art. 46 ust. 1 u.o.p., ochrona gatunkowa ma na celu zapewnienie przetrwania i właściwego stanu ochrony dziko występujących na terenie kraju lub innych państw członkowskich Unii Europejskiej rzadkich, endemicznych, podatnych na zagrożenia i zagrożonych wyginięciem oraz objętych ochroną na podstawie przepisów umów międzynarodowych, których Rzeczpospolita Polska jest stroną, gatunków roślin, zwierząt i grzybów oraz ich siedlisk i ostoi, a także zachowanie różnorodności gatunkowej i genetycznej. Jest to więc ochrona elementów runa leśnego w miejscu ich występowania (in situ), ale ustawodawca statuuje także ochronę roślin i grzybów zagrożonych wyginięciem ex situ, tj. poza miejscem ich występowania - w ogrodach zoologicznych, ogrodach botanicznych lub bankach genów (art. 47 ust. 1 u.o.p.). Jeżeli jednak rośliny i grzyby nie występują w wyżej wymienionych miejscach (zwłaszcza w ogrodach botanicznych) w formacjach leśnych (drzewostanach), to trudno w tym przypadku mówić o runie leśnym sensu stricto.

Zarazem runo leśne, które nie jest objęte ochroną szczególną (obszarowymi formami ochrony przyrody, na których terenie występuje jak również ochroną gatunkową), podlega ochronie powszechnej. Wynika to z dyspozycji art. 125 u.o.p., który wpro- 
wadza powszechną ochronę roślin, zwierząt i grzybów. Zgodnie z tym przepisem rośliny, zwierzęta lub grzyby, a także ich siedliska, nieobjęte formami ochrony przyrody mogą być niszczone lub zabijane jedynie w związku z: 1) realizacją zadań uzasadnionych potrzebami ochrony przyrody; 2) prowadzeniem badań naukowych lub edukacją; 3) racjonalną gospodarką; 4) amatorskim połowem ryb; 5) zbiorem na własne potrzeby; 6) prowadzeniem akcji ratowniczej; 7) bezpieczeństwem powszechnym; 8) bezpieczeństwem sanitarnym i weterynaryjnym; 9) ochroną życia i zdrowia ludzi; 10) zapobieganiem skutkom klęski żywiołowej lub ich usuwaniem. Warto zauważyć, że ustawodawca dopuścił tutaj wyjątki od powszechnej ochrony roślin i grzybów ze względu na m.in. zbiór na potrzeby własne (nie zaś przemysłowe), co z całą pewnością dotyczy płodów runa leśnego i w pełni koresponduje $\mathrm{z}$ unormowaniami ustawy o lasach.

Z powyższego wynika, że rośliny i grzyby, w tym gatunki tworzące runo leśne podlegają ochronie szczególnej, jeżeli znajdują się na terenie objętym obszarową formą ochrony lub ochroną gatunkową albo podlegają ochronie powszechnej, w sytuacji gdy nie zostały objęte ochroną szczególną ${ }^{54}$. Przy czym reżim ochrony szczególnej polega na tym, że ustawodawca całkowicie wyłącza dopuszczalność pozyskiwania (płodów) runa leśnego na własne potrzeby (a tym bardziej jego umyślnego uszkadzania lub niszczenia), bezwarunkowo chroniąc runo leśne jako istotny element przyrody. Bez względu jednak na konkretny rodzaj ochrony (ochrona szczególna, ochrona powszechna), runo leśne traktowane jest na gruncie przepisów ochrony przyrody jako jej składnik wymagający działań konserwatorskich, nawet jeżeli pojęcie runa leśnego nie zostało explicite wprowadzone do tekstu ustawy.

54 W. Radecki, Ustawa o ochronie przyrody. Komentarz, Warszawa 2008, s. $368-369$. 


\section{UWAGI KOŃCOWE}

Runo leśne jest integralnym składnikiem lasu. Zbieranie płodów runa leśnego - w ramach udostępniania lasów - stanowi przejaw powszechnego korzystania z ekosystemów leśnych, natomiast przemysłowe pozyskiwanie surowców roślin dna lasów jest korzystaniem szczególnym. Przepisy ustawy o lasach statuują model wielofunkcyjnej, trwale zrównoważonej gospodarki leśnej, której jednym z celów jest racjonalne użytkowanie runa leśnego zapewniające jego odpowiednią ochronę. Racjonalne pozyskiwanie użytków niedrzewnych jest bowiem ściśle związane z zachowaniem trwałego i zrównoważonego rozwoju lasów ${ }^{55}$.

Przegląd unormowań dotyczących ochrony runa leśnego oraz pozyskiwania jego płodów prowadzi do wniosku, że konieczne jest wprowadzenie bardziej szczegółowych regulacji normujących zasady użytkowania runa leśnego. Wynika to z kilku kluczowych przyczyn. Po pierwsze, pobieranie płodów runa leśnego - w odróżnieniu od surowca drzewnego - nie podlega certyfikacji ${ }^{56}$. Oznacza to, że jedynym certyfikowanym produktem wprowadzanym na rynek jest drewno. Po drugie, obserwuje się rabunkową eksploatację płodów runa leśnego. Mamy tutaj do czynienia z pewnego rodzaju paradoksem. Jedynie bowiem zbiór płodów runa leśnego dla celów przemysłowych wymaga zawarcia umowy. Tymczasem większość płodów runa leśnego pozyskiwanych na potrzeby własne jest sprzedawanych podmiotom prowadzącym działalność przetwórczą surowców ubocznego użytkowania lasu. W rezultacie niehandlowe pozyskiwanie płodów runa leśnego, jest w istocie zbiorem dokonywanym w celach handlowych. Po trzecie, wskazuje się na potrzebę kompleksowej inwentaryzacji bez surowcowych płodów runa

55 Z. Muszyński, J. Muszyński, Użytkowanie runa leśnego $w$ aspekcie zrównoważonego rozwoju leśnictwa $w$ Polsce, [w:] Użytkowanie lasu a trwały $i$ zrównoważony rozwój leśnictwa, D. F. Giefing, M. Bembenek (red.), Poznań 2005, s. 177-179.

56 Tamże, s. 178. 
leśnego ${ }^{57}$ oraz konieczność stworzenia „(...) zasad użytkowania runa leśnego, uwzględniających środowiskowe, społeczne i ekonomiczne aspekty użytkowania leśnej produkcji niedrzewnej"58.

Mimo pewnej ewolucji w tym zakresie, zwłaszcza podustawowych aktów wykonawczych, obowiązujące regulacje należy ocenić jako nie w pełni wystarczające i adekwatne do zapewnienia większej kontroli oraz bardziej zrównoważonego pozyskiwania płodów runa leśnego. Sądzę, że do realizacji tych celów mogłoby się przyczynić wprowadzenie - w drodze przepisów wykonawczych - regulacji ustanawiających cyklicznie i bieżąco aktualizowanych baz surowcowych runa leśnego z prognozowanym potencjałem produkcyjnym płodów tego surowca. Ponadto można byłoby wziąć pod rozwagę wprowadzenie dopuszczalnych limitów ilości zbiorów płodów runa leśnego dla potrzeb własnych. Dodatkowo warto zastanowić się nad zmianą brzmienia art. 153 Kodeksu wykroczeń określającego odpowiedzialność za wykroczenia popełnione przez podmioty w nienależącym do nich lesie. Chodzi tutaj w szczególności o wprowadzenie zbiorczej kategorii runa leśnego, zamiast wyodrębniania osobnych kategorii ziół, grzybów czy owoców leśnych. Znajduje to swoje uzasadnienie w tym, że wszystkie z nich wchodzą w skład runa leśnego, ale penalizowany jest zbiór (w zabronionych miejscach lub w niedozwolony sposób) wyłącznie grzybów i owoców leśnych, z pominięciem ziół oraz innych roślin runa leśnego (np. mszaków).

\section{BIBLIOGRAFIA}

Amann G., Rośliny runa, Warszawa 1994.

Ankudo-Jankowska A., Glura J., Znaczenie produktów ubocznego użytkowania lasu dla gospodarki leśnej, „Forestry Letters” 2013, T. 104.

57 K. Rykowski, O leśnictwie trwałym i zrównoważonym. W poszukiwaniu definicji i miar, Warszawa 2006, s. 139.

58 Tamże, s. 140 
Będkowska H., Niezbędnik edukatora, Warszawa 2010.

Bielecki L., Koncepcja rzeczy publicznej $w$ prawie polskim. Zagadnienia administracyjnoprawne, Kielce 2013.

Chmielewski J., Zasady ogólne gospodarki leśnej i prawa leśnego, „Krytyka Prawa. Niezależne studia nad prawem" 2015, T. 7.

Głowacki S., Zasoby leśnych surowców ubocznych oraz możliwości ich wykorzystania przez LP, Warszawa 2002.

Gmaj B., Ochrona gatunkowa grzybów w prawie polskim, „Przegląd Prawa Ochrony Środowiska" 2015, Nr 2.

Grochowski W., Uboczna produkcja leśna, Warszawa 1990.

Haładyj A., Trzewik J., Pojęcie strategicznych zasobów naturalnych uwagi krytyczne, „Przegląd Prawa Ochrony Środowiska” 2014, Nr 1.

Janusz A., Piszczek M., Udostępnianie lasów dla potrzeb turystyki i rekreacji na obszarze Regionalnej Dyrekcji Lasów Państwowych $w$ Krakowie, „Studia i Materiały Centrum Edukacji Przyrodniczo-Leśnej" 2012, r. 14, z. 32.

Jaszczak R., Funkcje lasów, [w:] Propedeutyka leśnictwa, W. Kusiak, R. Jaszczak, Poznań 2009.

Mała encyklopedia leśna, S. Kocięcki (red.), Warszawa 1991.

Muszyński Z., Muszyński J., Użytkowanie runa leśnego w aspekcie zrównoważonego rozwoju leśnictwa w Polsce, [w:] Użytkowanie lasu a trwały $i$ zrównoważony rozwój leśnictwa, D. F. Giefing, M. Bembenek (red.), Poznań 2005.

Orczewska A., Depa Ł., Rola rozkładającego się drewna i zasiedlajacych go mrówek $w$ migracji roślin runa leśnego, „Studia i Materiały Centrum Edukacji Przyrodniczo-Leśnej” 2014, r. 16, z. 41.

Pakuła J., Pojęcie i zasady gospodarki leśnej, [w:] Wybrane problemy prawa leśnego, B. Rakoczy (red.),Warszawa 2010.

Paschalis P., Założenia do zasad użytkowania lasu $w$ koncepcji trwałego i zrównoważonego gospodarowania lasami, „Sylwan” 1997, Nr 1.

Pawełek D., Zbieractwo grzybów, owoców, ziót i innych dóbr runa leśnego - zagrożenie i nadzieje, „Panacea” 2010, Nr 4.

Piwowar A., Zasoby leśne - Baza surowcowa $i$ znaczenie $w$ agrobiznesie, „Journal of Agribusiness and Rural Development” 2015, Nr 1.

Płotkowski L., Ekonomiczne aspekty oceny funkcji lasu, czyli gospodarka leśna w koncepcji zrównoważonego rozwoju, „Studia i Materiały Centrum Edukacji Przyrodniczo-Leśnej” 2008, r. 10, z. 3.

Płotkowski L., Zając S., Opracowanie modelu wielofunkcyjnej gospodarki leśnej w regionie rolniczym, Warszawa 2004.

Podstawy gospodarki leśnej, B. Ważyński (red.), Poznań 2014. 
Poznański R., Trwałość lasu i regulacja a ochrona przyrody $w$ lasach, „Studia i Materiały Centrum Edukacji Przyrodniczo-Leśnej” 2014, r. 16, z. 39.

Radecki W., [w:] M. Bojarski, W. Radecki, Kodeks wykroczeń. Komentarz, Warszawa 2013.

Radecki W., Ustawa o lasach. Komentarz, Warszawa 2012.

Radecki W., Ustawa o ochronie przyrody. Komentarz, Warszawa 2008.

Rakoczy B., Ustawa o lasach. Komentarz, Warszawa 2011.

Rykowski K., O leśnictwie trwałym i zrównoważonym. W poszukiwaniu definicji i miar, Warszawa 2006.

Stownik botaniczny, Warszawa 2003

Staniszewski P., Nowacka W. Ł., Leśne pożytki niedrzewne jako dziedzina nauki oraz element gospodarki leśnej, „Studia i Materiały Centrum Edukacji Przyrodniczo-Leśnej” 2014, r. 16, z. 38.

Stelmachowski A., Wykonywanie własności nieruchomości, [w:] System prawa prywatnego. Tom 3. Prawo rzeczowe, T. Dybowski (red.), Warszawa 2007.

Szewczyk E., Szewczyk M., Generalny akt administracyjny, Warszawa 2014.

Walas M., Korzystanie z lasów a trwale zrównoważona gospodarka leśna, [w:] Prawne aspekty gospodarowania zasobami środowiska. Korzystanie z zasobów środowiska, B. Rakoczy, M. Szalewska, K. Karpus (red.), Toruń 2014.

Zimmermann J., Aksjomaty prawa administracyjnego, Warszawa 2013. Zimmermann J., Prawo administracyjne, Warszawa 2014.

\section{Kontakt e-mail:}

jchmielewski@alk.edu.pl 